\title{
Alkoholvaner - født sånn eller blitt sånn?
}

Vi leger er rollemodeller - enten vi vil eller ikke. Sånn er det bare. Kanskje skal vi være glade for det, det betyr jo at det fremdeles er kraft i vår profesjonelle autoritet. På livsstilsområdet er dette særlig aktuelt. Fra å være blant de verste i klassen når det gjelder røyking, er norske leger blitt de beste, og det er grunn til å tro at legenes imponerende røykestatistikk er en av flere grunner til at også folk flest i økende grad stumper røyken. Når leger slutter, er det nok ikke primært fordi de vet mer enn andre om tobakkens skadelige virkninger, det er vel fordi det er sosialt ubehagelig å være røykende lege. Sosiale bremser kan være vel så effektive som individuelle.

På alkoholfeltet har også legene endret vaner. De drikker oftere i 2010 enn de gjorde i 2000, men det skjer sjeldnere at de drikker så mye at de blir skikkelig beruset ( 6 enheter), og de rapporterer færre negative konsekvenser av drikkingen (upubliserte data, Legeforeningen forskningsinstitutt). Men legene tar i mindre grad opp alkoholvaner enn røykevaner med pasientene sine (1).

Det å være rollemodell er også alle foreldres skjebne. Her kommer selvsagt genene inn i tillegg til sosial læring. Dette gjenspeiles i uttrykket «eplet faller ikke langt fra stammen». Noen ganger faller kanskje eplet langt fra stammen, særlig hvis stammen er lite bærekraftig. Disse eplene kan bli «løvetannbarn».

En interessant konsekvens av en slik omvendt logikk er bevegelsen Adult Children of Alcoholics (ACA) (2). Dette fellesskapet er basert på felles erfaring ved å ha vokst opp i et hjem preget av en eller to foreldre med alkoholavhengighet og alt det fører med seg av uforutsigbarhet, ansvar for småsøsken, kanskje overgrep og økt risiko for å bli avhengig selv. ACA har sprunget ut fra AA-bevegelsen i USA. De fleste medlemmene oppfatter seg som ikke-drikkende alkoholikere. Her har vi et helt bed med løvetannbarn!

Det er ikke bare foreldrene som lærer ungdommen å røyke og drikke, eldre søsken kan også spille en viktig rolle (3). Tidligere overlege i Statens helseundersøkelser Kjell Bjartveit (1927-2011) kunne fortelle om hvordan en uvanlig stor opphopning av røykende ungdomsskoleelever et sted i Trøndelag kunne spores tilbake til en populær håndballtrener som røykte. Slike lokale variasjoner synes å være regelen snarere enn unntaket. Grimsmo og medarbeidere viste for eksempel at det var stor variasjon i alkoholbruken blant ungdommen i tre relativt små nabokommuner i Midt-Norge $(4,5)$. Det var også betydelig variasjon innen hver kommune, en variasjon som ikke helt lot seg forklare ut fra spørreskjemadata fra de unge. De viktigste forklaringsvariablene for drikking var tidlig alkoholdebut, det å være ute om natten uten at foreldrene vet hvor man er, ha bestevenner som drikker mye og et høyt konsum av brus og potetgull. Undersøkelsen viste også at den vanligste drikkesorten blant disse 14-18 åringene, omregnet i ren alkohol, var hjemmebrent, at hver femte ungdom fikk alkohol hjemme, og at omtrent like mange tok alkohol hjemme.

I dette nummer av Tidsskriftet presenterer Haugland og medarbeidere en prospektiv undersøkelse der de i 1995-97 spurte ungdomsskoleelever om de noen gang hadde sett foreldrene sine beruset. I en ny undersøkelse fire år etter ble de samme elevene spurt om egne alkohol- og rusvaner (6). Artikkelen er basert på data fra Hel- seundersøkelsen i Nord-Trøndelag (HUNT). Ikke uventet finner de at ungdom i 18 -årsalderen med risikofylt rusbruk hadde signifikant større sannsynlighet for fire år tidligere å ha svart positivt på spørsmålet om de hadde sett sine foreldre beruset. De definerte risikofylt rusbruk på tre forskjellige måter: å ha drukket seg beruset mer enn ti ganger, å drikke alkohol hver uke eller oftere eller å ha prøvd hasj, marihuana eller liknende.

Det kan reises flere spørsmål rundt denne undersøkelsen, f.eks. hvordan ungdommen oppfatter spørsmålet om hvor ofte de har sett sine foreldre beruset. For noen vil nok dette referere til at foreldrene har en skikkelig «fylleatferd», for andre at de rett og slett ser at foreldrene drikker. Det er også grunn til å spørre om det å ha drukket seg beruset mer enn ti ganger, eller å ha prøvd hasj, marihuana aller lignende, bør karakteriseres som risikofylt rusbruk blant 18 -åringer.

Studien reiser også indirekte spørsmålet om hvordan foreldre til tenåringer bør introdusere sine håpefulle for alkoholen. Tenåringene beveger seg på en meget bratt læringskurve. De skal i løpet av få år gå fra et tilnærmet nullforbruk til et voksent alkoholkonsum. Denne opplæringen er i stor grad overlatt til tilfeldighetene. De viktigste «lærerne» er nok mer de toneangivende blant drikkekameratene enn foreldrene. Et interessant aspekt ved denne sosiale læringen er at det ikke bare er drikkemengde og drikkemåter som læres, man lærer også hvordan man bør oppføre seg under påvirkning av rusmidler. Sosialantropologene MacAndrew \& Edgerton viste for mange år siden at slik atferd kan variere fra det mest passive og ufarlige til kulturer der fylledrap er nærmest akseptert (7). Slik kunnskap bør skjerpe alle oss som er rollemodeller, enten vi er foreldre, ungdomsledere eller leger - som kjent teller det vi gjør mye mer enn det vi sier andre skal gjøre.

\section{Olaf Gjerløw Aasland}

olaf.aasland@legeforeningen.no

Olaf Gjerløw Aasland (f. 1944) er leder av Legeforeningens forskningsinstitutt og professor ved Institutt for helse og samfunn, Universitetet i Oslo. Han var i 1981-88 overlege i Statens edruskapsdirektorat, og satt i 1992-99 i WHOs Expert Advisory Panel on Drug Dependence and Alcohol Problems.

Ingen oppgitte interessekonflikter.

\section{Litteratur}

1. Nygaard P. Paschall M, Aasland OG et al. Use and barriers to use of screening and brief intervention for alcohol problems among Norwegian general practitioners. Alcohol Alcohol 2010; 45: 207-12.

2. Velkommen til ACA. www.acanorge.org (7.1.2012).

3. Kim MJ, Fleming CB, Catalano RF. Individual and social influences on progression to daily smoking during adolescence. Pediatrics 2009; 124: 895-902.

4. Grimsmo A, Storset B, Ødegaard JA. Alkoholkonsum blant ungdom i tre kommuner. Tidsskr Nor Lægeforen 1995; 115: 2759-63.

5. Grimsmo A, Storset B, Ødegaard JA. Utvikling av alkoholvaner blant ungdom. Tidsskr Nor Lægeforen 1995; 115: 2764-67.

6. Haugland SH, Strandheim A, Bratsberg G. Er risikofylt rusmiddelbruk vanligere blant ungdom som har sett foreldrene beruset? Tidsskr Nor Legeforen 2012; 132: $410-3$.

7. Edgerton RB, MacAndrew C. Drunken comportment: a social explanation. Chicago: Aldine Publishing Company, 1969, 